\title{
PENGGUNAAN MODUL ILUSTRATIF BERBASIS INKUIRI TERBIMBING POKOK BAHASAN KINEMATIKA GERAK LURUS UNTUK MENINGKATKAN HASIL BELAJAR DAN KEMANDIRIAN SISWA KELAS VII SMPN 14 MADIUN
}

\author{
Andista Candra Yusro ${ }^{1}$, Mislan Sasono² \\ ${ }^{1,2}$ Program Studi Pendidikan Fisika, Fakultas PMIPA, IKIP PGRI MADIUN \\ Email: ${ }^{1}$ andista@ikippgrimadiun.ac.id; ${ }^{2}$ mislan@ikippgrimadiun.ac.id
}

\begin{abstract}
Abstrak
Penerapan modul dalam pembelajaran IPA pada siswa kelas VII SMPN 14 Madiun pada pokok bahasan kinematika gerak lurus dengan menggunakan modul ilustratif berbasais inkuiri terbimbing. Pembelajaran dilaksanakan dalam 3 siklus pembelajaran. Penggunaan modul ilutratif berbasis inkuiri terbimbing dalam memberlajarkan materi kinematika gerak lurus pada siswa SMP efektif dalam meningkatkan hasil belajar dan kemandirian siswa. Peningkatan hasil belajar tercermin dari rata-rata ketuntasan hasil belajar siswa secara klasikal saat mengikuti pembelajaran pada siklus I 60\%, siklus II 80\% dan siklus III 96\%. Kemandirian siswa tercermin dari antusiasme siswa dalam megikuti pembelajaran dengan menggunakan modul ilustrtatif hal ini berdasarkan pengamatan dan hasil wawancara dilakukan kepada siswa. Seluruh isian aktifitas siswa maupun latihan-latihan yang ada dalam modul baik itu merupakan tugas individu maupun tugas kelompok mampu diselesaikan dengan baik oleh siswa.
\end{abstract}

Kata kunci : Modul Ilustratif, Inkuiri Terbimbing, Kinematika Gerak Lurus, Hasil Belajar, Kemandirian

\section{PENDAHULUAN}

Pendidikan merupakan proses dalam pembangunan manusia untuk mengembangkan dirinya agar dapat menghadapi segala permasalahan yang timbul pada diri manusia itu sendiri. Menurut Undang-Undang tentang sistem pendidikan nasional, pendidikan adalah usaha sadar dan terencana untuk mewujudkan suasana belajar dan proses pembelajaran agar peserta didik secara aktif mengembangkan potensi dirinya untuk memiliki kekuatan spiritual keagamaan, pengendalian diri, kepribadian, kecerdasan, akhlak mulia, serta keterampilan yang diperlukan dirinya, masyarakat, bangsa, dan negara. (UU No. 20 Tahun 2003). Pendidikan karakter dapat dimaknai sebagai pendidikan untuk mengembangkan kepribadian atau akhlak peserta didik sesuai dengan cita-cita luhur pendidikan nasional, sehingga peserta didik menjadi seseorang yang berakhlak mulia, berbudi pekerti luhur, disamping tentu saja, menguasai berbagai pengetahuan dan keterampilan yang memungkinkannya menjadi manusia Indonesia seutuhnya. Dengan kata lain, kepribadian seseorang manusia mencerminkan semua ranah kemampuan, kognitif, keterampilan, dan afektif karena pada dasarnya ketiga ranah tersebut merupakan satu kesatuan yang utuh.

Keberadaan modul saat ini masih masih bersifat verbal atau tekstual sehingga peserta didik masih merasa kurang tertarik untuk membacanya. Agar peserta didik mau membaca dan mudah memahaminya, perlu dikembangkan modul dengan disertai gambar atau ilustrasi. Karena sifatnya yang konkrit, media gambar atau ilustrasi lebih realistis menunjukkan pokok masalah dibandingkan dengan media verbal semata. Selain itu, media gambar atau ilustrasi dapat memperjelas penyampaian pesan dalam media verbal. Keterbatasan ruang dan waktupun dapat teratasi dengan media ini. (Sadiman. 2011:29)

Ilustrasi sangat penting keberadaannya karena kebermanfaatannya untuk menjelaskan 
JPFK, Vol. 2 No. 1, Maret 2016, hal 29 - 35 http://e-journal.ikippgrimadiun.ac.id/index.php/JPFK

tujuan materi yang ingin disampaikan. Oleh karena itu Prasetio (20112:8) mengungkapkan penggunaannya perlu dirancang secara matang agar tidak sekedar sebagai pendukung bentuk komunikasi verbal yang selama ini begitu dominan dalam pembelajaran yang kemudian menimbulkan masalah pengalaman belajar yang verbalistik dalam dunia pendidikan kita. Ilustrasi yang baik, dapat menjelaskan tujuan yang ingin disampaikan dengan mudah dan tanpa makna jamak.

Pembelajaran Fisika SMP pada materi Kinematika khususnya pada bahasan gerak lurus yang diselenggarakan di SMPN 14 Madiun masih bersifat textual yang mengandalkan kepada buku teks pembelajaran dan LKS yang berisi soal-soal dan pembahasan. Pembelajaran dengan pendekatan tersebut mengakibatkan pembelajaran terpusat kepada guru, aktifitas siswa hanya pada menyelesaikan soal-soal yang ada di LKS dan buku pembelajaran. Dampak selanjutnya dari pembelajaran yang digunakan pada materi Gerak Lurus dengan jumlah siswa yang lulus tanpa remidial sebanyak $40 \%$.

Dalam pembelajaran sains dengan pembelajaran inkuiri, guru harus membimbing siswa terutama siswa yang belum pernah mempunyai pengalaman belajar dengan kegiatankegiatan inkuiri. Winarni (2009) menyatakan bahwa melalui inkuiri, guru mengajak siswa untuk lebih aktif baik fisik maupun mental dalam proses belajar. Menurut Jannah, dkk (2012) dengan penerapan inkuiri terbimbing dapat meningkatkan kualitas pemahaman konsep siswa dan mampu tertanam karakter pada siswa.

Materi Gerak Lurus adalah materi yang sangat penting untuk dipelajari. Hal ini dikarenakan Gerak Lurus adalah dasar untuk mempelajari materi selanjutnya seperti usaha dan energi, kinematika gerak dua dimensi, hingga fisika modern dan fisika kuantum akan mensyaratkan materi gerak lurus ini untuk dikuasai terlebih dahulu. Selain itu aplikasi materi ini dalam kehidupan sehari-hari yang melimpah di sekitar kehidupan siswa, membuatnya harus dikuasi untuk kemudian siswa dapat menjadikannya alasan dalam bertindak dan mengambil keputusan dalam permasalahan yang mereka hadapi sehari-hari.
Pemilihan metode yang tepat dalam mebelajarkan materi gerak ini menjadi salah satu kunci utama dalam membangun pemahaman siswa. Oleh karena itu, hal ini menjadi hal yang penting juga menggunakan sebuah modul sebagai penunjang pelaksanaan pembelajaran fisika pada materi kinetik gas. Kemajuan teknologi menghadirkan wahana baru dalam proses pembelajaran. Jaringan internet yang saat ini dapat dirasakan di berbagai daerah, menjadi salah satu gerbang utama masuknya informasi. Hal ini dapat memicu pesatnya perkembangan ilmu pendidikan dan teknologi. Media internet dapat dimanfaatkan oleh siswa dalam proses pembelajaran untuk mendapatkan info-info terbaru mengenai materi yang sedang dibahas, sehingga siswa pun dapat memiliki pengetahuan yang lebih baik dari sebelumnya. Perkembangan teknologi semakin memanjakan siswa untuk mengakses internet. Siswa dapat mengakses internet melalu komputer, laptop, tablet, maupun smartphonenya, sehingga informasi itu dapat dengan mudah sampai ke siswa.

Modul merupakan salah satu media berbasis cetak. Keterbatasan modul dalam menampung info-info terbaru perlu disiasati dengan cara diberi tambahan berupa alamat situs/web yang dapat diakses siswa guna mendapatkan pemahaman atau info yang lebih lanjut. Dengan diberikannya alamat situs/web dalam modul, siswa dapat meninjau secara langsung sumber ilmu, pemanfaatan, dan pengembangannya. Menyadari tidak semua daerah memiliki jaringan internet, maka perlu alternatif berupa pemberian $\mathrm{CD}$ yang berisi kumpulan halaman situs/web yang terdapat di dalam modul, sehingga siswa dapat mengaksesnya kapan saja tanpa membutuhkan koneksi internet dengan komputer.

\section{METODE PENELITIAN}

Metode yang digunakan dalam penelitian ini adalah metode Penelitian Tindakan Kelas (Classroom Action Research). Model PTK yang digunakan dalam penelitian ini adalah Model Spiral dari Kemmis-Mc. Taggart (1988).

Model yang dikembangkan oleh Kemmis dan Mc. Taggart ini dilakukan melalui empat 
JPFK, Vol. 2 No. 1, Maret 2016, hal 29 - 35

http://e-journal.ikippgrimadiun.ac.id/index.php/JPFK

tahapan mulai dari perencanaan, pelaksanaan, obsevasi dan refleksi. Alur Siklus tersebut saling kerkelanjutan dan berkesinambungan. Siklus pertama dilakukan berdasarkan masalah yang teramati, jika hasilnya masih kurang maka dilanjutkan ke siklus berikutnya yang merupakan perbaikan dari siklus pertama. Siklus dihentikan jika hasil penelitian di rasa sudah cukup dan memenuhi tujuan yang diharapkan.

Proses penelitian diselenggarakan di SMPN 14 Madiun. Adapun yang menjadi subjek dalam penelitian ini adalah siswa kelas 7A tahun pelajaran 2015/2016 semester gasal yang berjumlah 24 siswa. Kegiatan pembelajaran dikelas dilakukan dengan ditemani oleh 2 orang sebagai pengamat yang akan mengamati pembelajaran dengan menerapkan modul ilutratif berbasis inkuiri terbimbing.

\begin{tabular}{|c|c|c|}
\hline No. & Komponen Nilai & Nilai (Presentase) \\
\hline 1. & Rata-rata pretest & 30 \\
\hline 2. & Rata-rata posttest & 68 \\
\hline 3. & Kentuntasan Individual & $50 \%$ \\
\hline 4. & Kentuntasan Klasikal & $60 \%$ \\
\hline
\end{tabular}

Tabel 1. menunjukkan secara keseluruhan mengammbarkan bahwa pada siklus I rata-rata nilai prestes siswa diperoleh tergolong rendah 30 , hal ini dikarenakan mayoritas siswa tidak belajar dan belum terbiasa dengan adanya test sebelum dimulainya pembelajaran. Rata-rata nilai posttest yang didapatkan oleh siswa pada akhir proses pembelajaran siklus I diperoleh 68, apabila kita tinjau dari ketuntasan individual dari sebanyak 24 siswa ada 12 orang siswa yang belum tuntas sementara tingkat ketuntasan siswa secara klasikal adalah $60 \%$.

Beradasarkan hasil pengamatan dalam pelaksanaan pembelajaran pada siklus I didapatkan fakta dilapangan bahwa sebagian besar aktivitas guru adalah membimbing siswa dalam memahami dan mengerjakan tugas-tugas

\section{HASIL DAN PEMBAHASAN}

Berdasarkan hasil penelitian, maka dapat dijelaskan bahwa, adanya peningkatan presentase ketuntasan individual secara keseluruhan antara siklus pertama, kedua dan ketiga. Berdasarkan analisis data observasi selama tiga siklus sebagai mana diuaraikan sebagai berikut :

Siklus I

Siklus I dilaksanakan berdasarkan perangkat pembelajaran yang telah direncanakan, pelaksanaan pembelajaran dilaksanakan dikelas 8A SMPN 14 Kota Madiun diamati oleh dua orang pengamat. Adapun hasil tes pada saar sebelum dan sesudah pembelajaran pada siklus I sebagai berikut :

Tabel 2. Hasil Belajar Pada Siklus II SMPN 14 Madiun

\begin{tabular}{llc}
\hline No. & \multicolumn{1}{c}{ Komponen Nilai } & Nilai (Presentase) \\
\hline 1. & Rata-rata pretest & 50 \\
\hline 2. & Rata-rata posttest & 80 \\
\hline 3. & Kentuntasan Individual & $78 \%$ \\
\hline 4. & Kentuntasan Klasikal & $80 \%$ \\
\hline
\end{tabular}


JPFK, Vol. 2 No. 1, Maret 2016, hal 29 - 35 http://e-journal.ikippgrimadiun.ac.id/index.php/JPFK

Berdasarkan data pada table 2. secara keseluruhan menggambarkan bahwa pada siklus II adalah nilai rata-rata pretest yang diperoleh siswa 51 sedangkan nilai rata-rata posttest yang diterima siswa sebesar 80. Sedangkan apabila ditinjau dari ketuntasan individual sebanyak 78 siswa dinyatakan lulus dan untuk ketuntasan klasikal sebesar $80 \%$.

Aktivitas guru dan siswa berlangsung selama pembelajaran penerapan modul ilustratif berbasis inkuiri terbimbing diamati dengan menggunakan lembar aktivitas guru dan siswa. sebagian besar aktivitas guru pada siklus II adalah membimbing siswa dalam memahami dan mengerjakan tugas-tugas pada modul pembelajaran dengan prosentase sebesar $12.25 \%$. aktivitas siswa yang paling dominan adalah melakukan aktivitas belajar dengan modul kegaiatan II bagian 1 dan mempelajari terkait dengan mengaitkan konsep yang telah dipelajari pada modul dengan pengetahuan yang dimilikinya terkait dengan kehiduapan sehari-hari. pada siklus II kenaikan nilai pretest dan postetest sebesar 30.

Hasil belajar pada siklus III setelah diawali dengan pemberian pretest sebelum kegiatan pembelajaran pada siklus III dan diakhiri dengan posttest. Terdapat peningkatan hasil belajar siswa baik pada saat pelaksanaan pretest maupun posttest hal ini diindikasi terjadi karena siswa mulai terbiasa dengan pola pembelajaran yang diterapkan. Perubahan pola kemandirian siswa juga terbentuk berdasarkan pengamatan pelaksanaan pretest dan posttest yang dilakukan mulai dari siklus I sampai dengan siklus III. Kemandirian siswa tersebut tercermin dari adanya peningkatan nilai pretest dapat diartikan pula siswa memiliki pengetahuan awal dengan bersedia mempelajari terlebih dahulu materi yang akan diajarkan pada pertemuan selanjutnya. Secara garis besar hasil belajar pada siklus III dapat dilihat pada tabel 3 .

Tabel 3. Hasil Belajar Pada Siklus III SMPN 14 Madiun

\begin{tabular}{llc}
\hline No. & Komponen Nilai & Nilai (Presentase) \\
\hline 1. & Rata-rata pretest & 60 \\
\hline 2. & Rata-rata posttest & 88 \\
\hline 3. & Kentuntasan Individual & $100 \%$ \\
\hline 4. & Kentuntasan Klasikal & $96 \%$ \\
\hline
\end{tabular}

Tabel 3. diatas diatas secara keseluruhan menggambarkan bahwa pada siklus III adalah nilai rata-rata pretest yang diperoleh siswa 60 sedangkan nilai rata-rata posttest yang diterima siswa sebesar 88 . Sedangkan apabila ditinjau dari ketuntasan individual sebanyak 23 siswa dinyatakan lulus dan untuk ketuntasan klasikal sebesar $96 \%$. Pada siklus III ini seharusnya ada jumlah siswa yang masuk 23 sehingga ketuntasa individual $100 \%$ dikarenakan tuntas semua akan tetapi secara klasikal hanya $96 \%$. Aktivitas guru pada siklus III ini lebih intens kepada mendampingi siswa yang mengalami kesulitan dalam mempelajari modul kegiatan III. Apabila pada siklus I dan II guru berusaha membimbing seluruh siswa dalam kelompoknya masing-masing dalam mempelajari modul berbeda dengan pada siklus III guru sebagai konsultan saja menerima murid yang mengalami kesulitan dalam memahami modul yang diberikan. Aktivitas siswa tentunya hanya berpusat pada kegiatan mandiri bersama dengan kelompoknya masing-masing mempelajari modul kegiatan III dengan sesekali beberapa diantara mereka menghampiri guru untuk mendapatkan penjelasan dan penguatan. Siswa lebih enjoy pada saat mengerjakan soal posttest dikarenakan siswa yakin apabila mereka mempelajari modul kegiatan III dengan baik dan seksama maka korelasi postitifnya mereka mampu mengerjakan soal posttest denga baik.

Pada prinsipnya berdasarkan hasil pengamatan yang dilakukan oleh pengamatan 
JPFK, Vol. 2 No. 1, Maret 2016, hal 29 - 35

http://e-journal.ikippgrimadiun.ac.id/index.php/JPFK

dalam pelaksanaan pembelajaran dengan pengunaan modul pembelajaran ilustrtatif berjalan baik sesuai dengan skenario yang tertuang dalam perangkat pembelajaran yang telah disusun pada tahapan perencanaan pembelajaran. Yusro (2015) dalam pembuatan modul yang terintgrasi dengan website diharapkan siswa mampu belajar dengan memanfaatkan ICT sehinga mampu mengikuti

perkembangan zaman. Pada pembelajaran yang didesain pada penelitian beberapa kasus yang terdapat pada modul pembelajaran dicoba untuk diarahkan kepada terintegrasi dengan website diamana untuk menetukan jarak tempuh pada pada suatu kasus siswa diminta langsung menggunakan fasilitas internets kaitannya dengan google maps, sesuai dengan gambar 1.

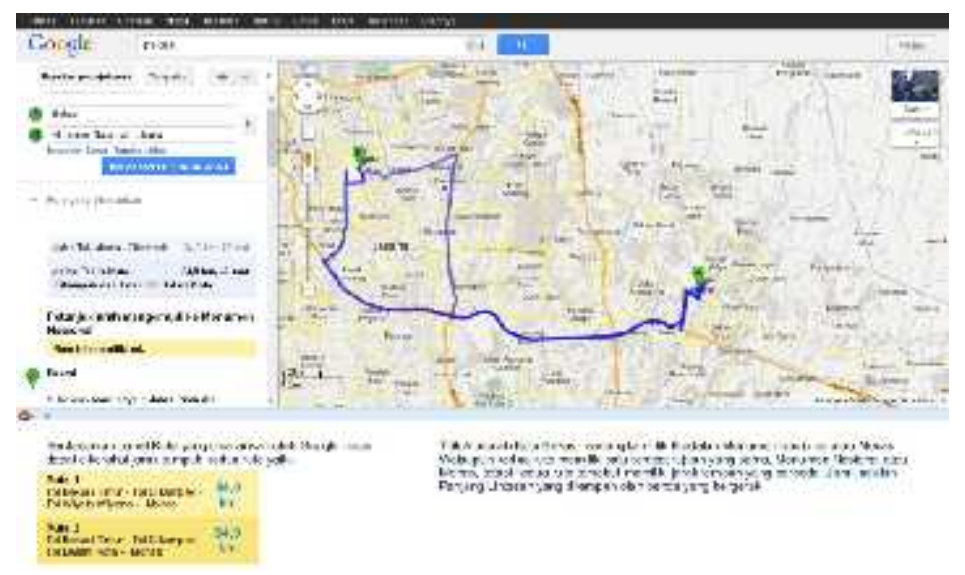

\section{Gambar 1. Siswa diminta menetukan jarak antara A dan B dengan menggunakan Google Maps}

Pembelajaran dengan modul ilustratif yang berisi gambar menarik dan beberapa kasus di modul yang merngharuskan siswa untuk berinteraksi dengan perangkat yang mampu terkoneksi dengan internet ternyata berkorelasi positif dalam memupuk kemandirian siswa dalam mempelajari materi kinematika gerak lurus. Beberapa contoh aktivitas siswa dalam mengerjakan aktivitas siswa dalam modul yang dilakukan secara kelompok akan tetapi dalam pelaporannya dilaporkan secara mandiri dan siswa diharuskan untuk menuliskan kesimpulan sendiri juga merupakan bentuk melatihkan kemandirian siswa dalam belajar. Lembar aktivitas siswa dalam modul ilustratif seperti pada gambar 2 .

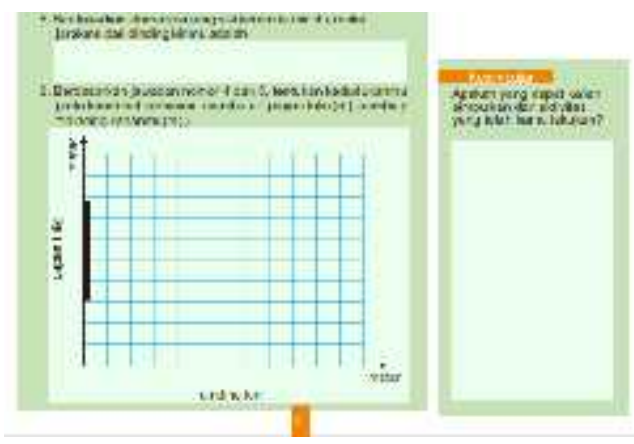

Gambar 2. Contoh Lembar Aktivitas Siswa dalam Modul Ilustratif 
JPFK, Vol. 2 No. 1, Maret 2016, hal 29 - 35

http://e-journal.ikippgrimadiun.ac.id/index.php/JPFK

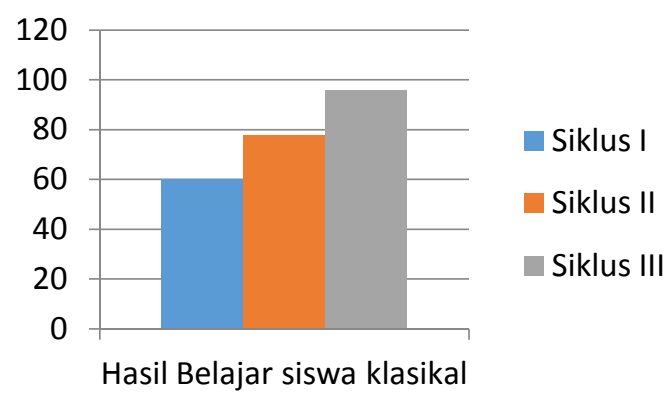

Gambar 3. Perbandingan Ketuntasan Hasil Belajar Fisika Secara Klasikal

Pelaksanaan pembelajaran pada siklus I, II dan III dapat terlaksana dengan baik tentunya ditunjang dengan perencanaan yang matang yang teruang dalam perangkat pembelajaran. Yusro (2016) dalam penelitiannya terkait dengan pengembangan perangkat pembelajaran didapatkan hasil yang sangat baik. Hal ini sebagai indikasi dalam melakukan penelitian tindakan diperlukan perencanaan yang baik, perencanaan yang baik itu tertuang dalam sebuah perangkat pembelajaran yang baik dengan harapan porses siklus yang dilakukan dalam penelitian tindakan ikut baik karena berpedoman pada perangkat pembelajaran yang dibuat secara tersstruktur dan sistematis.

Ketuntasan belajar siswa pada penelitian ini menunjukkan bahwa respon siswa dalam mengikuti pembelajaran pada materi kinematika gerak lurus dengan bantuan modul ilustratif dalam kategori baik. Kategori baik itu didapatkan apabila kita amati progress perbandingan ketuntasan siswa secara klasikal dari Siklus I, II dan III. Pada siklus I ketuntasan secara klasikal adalah $60 \%$, meningkat pada siklus II menjadi $80 \%$ dan pada siklus III ketuntasan secara klasikal sebesar 96\%. Secara garis besarcapaian ketuntasan siswa secara klasikal dapat dilihat pada gambar 3 .

Respons siswa cukup baik dalam mengikuti pembelajaran IPA pada materi kinematika gerak lurus dengan menggunakan modul ilustratif berbasis inkuiri terbimbing. Berdasarkan hasil wawancara dengan siswa terkait dengan pembelajaran dengan menggunakan modul ilutratif tersebut, beberapa memberikan komentar dan rata-rata komentar siswa siswa sangat baik, adanya modul yang berisi gambar yang menarik dan diintegrasikan dengan ICT menurut mereka sesuai dengan kebutuhan belajar saat ini. Mereka nyaman belajar dengan menggunakan modul tersebut dikarenakan didalam modul yang digunakan tidak hanya berisi materi pelajaran, latihan soal akan tetapi berisi aktifitas siswa yang harus mereka lakukan baik itu secara kelompok maupun individu yang disertai dengan petunjuk yang jelas dan ilutrasi gambar menarik. Kegiatan siswa pada point aktifitas siswa dalam modul mampu melatihkan kemandirian belajar siswa. Purwandari et all mengungkapkan bahwa pembelajaran dengan inkuiri terbimbing mampu melatihkan siswa dengan baik dalam mempelajari konsep-konsep sains khususnya fisika, hal ini sejalan dengan hasil penelitian yang telah dilakukan yakni penerapan modul ilutratif berbasis inkuri terbimbing mampu meningkatkan hasil belajar dan kemandirian siswa.

\section{KESIMPULAN DAN SARAN}

Penggunaan modul pembelajaran IPA berbasis inkuiri terbimbing pada pokok bahasan kinematika gerak lurus mampu meningkatkan hasil belajar siswa sesuai dengan hasil penelitian yang menunjukkan ketuntasan hasil belajar siswa yang mengalami kenaikan dari siklus I sebesar $60 \%$, siklus II $80 \%$ dan siklus III 60\%. Modul yang berbasis inkuiri terbimbing yang didalamnya memuat aktifitas yang harus dilakukan siswa baik secara kelompok maupun individu mampu meningkatkan kemandirian siswa dalam mempelajari materi IPA khususnya kinematika gerak lurus. Karateristik anak SMP yang menyuka buku bergambar sangat cocok dengan penerapan modul yang ilutratif yang 
JPFK, Vol. 2 No. 1, Maret 2016, hal 29 - 35 http://e-journal.ikippgrimadiun.ac.id/index.php/JPFK

mampu mengkomunikasikan materi ajar dengan gambar-gambar yang menarik dan kekinian dan dikombinasikan dengan langkah-langkah pembelajaram inkuiri terbimbing dirasa sangat cocok untuk membelajaran IPA pada siswa SMP khususnya materi kinematika garis lurus.

\section{UCAPAN TERIMAKASIH}

Penulis mengucapkan terima kasih kepada program penelitian skim Peneltian Dosen Pemula tahun anggaran 2015, sumber dana LPPM IKIP PGRI MADIUN.

\section{DAFTAR PUSTAKA}

Departemen Pendidikan Nasional, (2003). Undang-Undang Nomor 20 Tahun 2003, Tentang Sistem Pendidikan Nasional, Jakarta: Depdiknas.

Jannah, M, dkk. 2012. Pengembangan Perangkat Pembelajaran Berorientasi Nilai Karakter Melalui Inkuiri Terbimbing Materi Cahaya Pada Siswa Kelas VIII Sekolah Menengah Pertama. Journal of Innovative Science Education. Vol. 1 (1): 54-60.

Kemmis, S dan R. Mc Taggart. (1988). The Action Research Planner. Victoria: Deakin University.

Sadiman, dkk. (2011). Media Pendidikan, Pengertian, Pengembangan, dan Pemanfaatannya. Jakarta: PT. Raja Grafindo Persada.
Prasetio. Adhi. (2012). Buku Pintar Pemrograman Web. Jakarta : Mediakita

Purwandari, P., Huriawati, F., \& Yusro, A. C. (2015). EFEKTIFITAS INQUIRY TERBIMBING DAN INQUIRY BEBAS TERMODIFIKASI MELALUI EKSPERIMEN TERHADAP HASIL BELAJAR FISIKA DITINJAU DARI KEMAMPUAN AWAL, KREATIFITAS, KEMAMPUAN BERPIKIR ABSTRAK SISWA KELAS X SMA NEGERI 6 KOTA MADIUN TAHUN AJARAN 2010/2011. Jurnal Pendidikan, 18(1).

Winarni, E. (2009). Pengembangan Model Pembelajaran Inkuiri Terbimbing Dan Masyarakat Belajar Untuk Meningkatkan Pemahaman Konsep dan Life Skill Siswa Sekolah Dasar. Jurnal Pendidikan Dasar. Vol. 10 (1): 1-7.

Yusro, A. C. (2015). PENGEMBANGAN MODUL PEMBELAJARAN FISIKA BERBASIS KONTEKSTUAL YANG TERINTEGRASI DENGAN WEBSITE PADA SISWA KELAS XI IA SMA NEGERI 5 MADIUN TAHUN AJARAN 2012/2013 (Doctoral dissertation, Universitas Sebelas Maret).

Yusro, A. C. (2016). PENGEMBANGAN PERANGKAT PEMBELAJARAN FSIKA BERBASIS SETS UNTUK MENINGKATKAN KEMAMPUAN BERPIKIR KREATIF SISWA. JURNAL PENDIDIKAN FISIKA DAN KEILMUAN, 1(2), 61-66. 